There were important earth-movements at the close of the Cambrian in the Welsh - Midlands region, involving uplift and erosion of the Cambrian sediments. These movements defined the limits of the Welsh geosyncline during the Ordovician, the margins of which lay approximately in Anglesey and in Shropshire. The Builth-Llandrindod inlier of Central Wales reveals an early Ordovician shore-line which is preserved with remarkable clarity, while dolerite intrusions of Ordovician age display laccolithic structures of unique types. The Ordovician rocks of the Lake District were deposited in the north-eastward continuation of the Welsh geosyncline; on the west, the St. George's Channel - Irish Sea area was geanticlinal, and to the east and north-east of Shropshire lay the main land-mass on that side of the trough. There was widespread volcanic activity as well as important contemporaneous earthmovements.

The Durness Limestone in the North-West Highlands must be referred mainly to the Ordovician, and while these calcareous rocks were being deposited, clastic sediments, accompanied by volcanic activity, were being laid down in early Ordovician times in the Southern Uplands, Girvan and probably the Highland Border. Then followed uplift and erosion in southern Scotland; but the facies distribution of the upper Ordovician suggests land to the north of Girvan, and the presence between it and the Irish Sea geanticline of a geosyncline, which continued south-westwards into Ireland. It would appear that the area north of the Highland Border was affected by these middle Ordovician movements, but it may also have been affected by those in the CambroOrdovician interval which were so evident in the Welsh-Midlands region. These earlier movements may possibly be responsible for the incomplete Cambrian succession in the North-West Highlands.

The Welsh geosyncline was maintained during the Silurian although there was a considerable change in the character of sedimentation, and in certain places uplift and erosion of the older rocks; but beginning with the Upper Llandovery and continuing throughout the Wenlock and Ludlow, the sea spread eastwards and southwards over areas which had been land during the Ordovician. There is evidence of the westerly derivation of material from the St. George's Channel-Irish Sea region; in Central Wales during the Middle and Upper Llandovery and in North Wales during the Wenlock and Ludlow; the Ludlow rocks reveal extensive submarine sliding and slumping of the sediments. The Welsh geosyncline still extended into the Lake District, but there is no evidence that the sea transgressed widely over the eastern stable area.

The Girvan-Moffat geosyncline persisted, and there are indications of an easterly derivation of material during the Upper Llandovery and Wenlock, suggesting separation from the Wales-Lake District trough ; Ludlow rocks are only found in the Midland Valley, and it is not known whether they were deposited in the Southern Uplands.

The Downtonian rocks, which were deposited in basins and lagoons where at times conditions approached continental, are restricted to the southeastern and north-western flanks of the Silurian tract. They may not have been deposited in the central region of North Wales, the Lake District and the Southern Uplands because it was being uplifted and eroded as a result of the onset of the Caledonian orogeny.

\section{ZOOLOGY OUTSIDE THE LABORATORY}

TN his presidential addoss to Section D, Prof. A. C. Hardy stress 4 the importance of zoological field studies. Fcologf, by developing quantitative and experimen fe noethods, is converting natural history intorscieng Its aim is not simply to express the inferpationships of organisms with their environment numerical terms-in itself a tedious refinement-but from such analysis to discover more of the laws operating in animate Nature.

It may seem strange that animal ecology should be so much more advanced in the hidden world of the sea than it is on land. We know more about the food relations of many fish than we do of any terres. trial animals. We have a better idea of the populations, per unit area, of different molluscs on parts of the sea floor than of the snails of our countryside; our knowledge of the numbers of small crustacea per cubic metre of water in many seas is far in advance of that regarding insect numbers on land. Possibly we know more about the ecology of the Dogger Bank and its overlying waters than about that of any English county.

We should not claim a greater marine enthusiasm. Of our food supply, the fish and whales are alone unfarmed and still hunted in the wild. It is, of course, the economic urge to find out more and more about them, so as to exploit them more efficiently, that financially has stimulated ecology under the sea. If only cattle and sheep had never been domesticated, what a wonderful series of terrestrial investigations we might have had by now, to enable us to conserve the stocks of wild game and use them to the best advantage. But is not ecology on land really just as vital-but not quite so obvious? While the main sources of our food are cultivated plants and domesticated animals, they are attacked by a multitude of wild pests. It is true that there are now dotted about the world many research stations, but most of these deal either with the control of certain pests, or with the biology of some particular kind of plant or animal. How many are devoted to the science of wild life for its own sake? At present very few. Yet it can only be through a better understanding of the basic principles underlying the complex interactions of wild life that really sound progress can be made towards a better knowledge of the factors governing our food supply.

That, indeed, is urgent; but such pure research in field zoology is important for a much more fundamental reason. Man does not live by bread alonenot man as most of us respect him. If he does come so to live-and it is a possibility-our civilization will change. Who can doubt that the roots of the two World Wars were not nourished to a large extent upon a philosophy of materialism and too small a knowledge of the working of evolution? If we could spend upon fundamental biology half as much as we spend upon research on atomic energy, how much more we would know about the very nature of life and the process of evolution. The study of evolution in action is one of the most exciting themes in ecology, for many of its problems can only be solved outside the laboratory.

We want more evidence in quantitative terms of the actual operation of selection in Nature. Are the very small isolated populations in which genetic drift can give rise to non-adaptive variations really important? Can they usually survive for long enough 
to provide in time the pre-adaptive forms which may take advantage of some new situation in the changing environment? A still more important contribution that field zoology can make to evolutionary theory is to throw more light on the part played by organic selection. The gene combinations which are best suited to the habits of the animal may tend to survive in preference to those which do not give such full scope to the animal's pattern of behaviour. This idea, put forward independently by Baldwin and Lloyd Morgan at the turn of the century, may, indeed, be a factor of importance.

There has now appeared over the horizon something which many do not like to look at, namely, telepathy. Prof. Hardy believes that no one who examines the evidence with an unbiased mind can reject it; particularly the evidence from many experiments (made by several independent workers) which have passed the statistical tests regarded as decisive in normal scientific technique. Such a discovery should make us keep our minds open to the possibility that there may be so much more in living things and their evolution than our science has hitherto led us to expect.

$$
\text { gof }
$$

\section{THE PLANNING OH}

$\mathrm{T}$ HE development \&f geographical thought over the past half-centu has been marked by the emergence of a logical pattern of cause and effect and by the demongtion of the influence of environmental factopan human life. Prof. L. Dudley Stamp points out ip his presidential address to Section E (Geofraphy), that the stage has now been reached when goophosical methods of survey and analysis, and further, of synthesis, can be and should be applied and used so as to assist in the solution of the great social problems of the world to-day. In particular, in the field of land-use planning, there is considerable justification for the assertion that geography is the science of which land planning is the art.

Every country has two ultimate assets-its land and its people. The planning of land use is no more and no less than planning for the full development and use of natural resources, notably of food-producing land. It must be viewed against a world background of expanding population but fixed land area, where there are no longer vast tracts of virgin land available for easy conquest, even though the tropical lands are eventually brought into full production. Good land is becoming rapidly scarcer, and modern land planning involves a balance between competing demands. Land is needed for at least six basic needs of man : for the siting of industrial works, for homes, for food and associated raw materials, for recreation, for communications, for security or defence. The problem of securing a just balance between these competing demands is acute in a country such as Britain with only a little more than an acre per head-less than half an acre of food-producing farmland. Although a multiple use of many types of land is possible and a concept of 'optimum use' for any given tract may be developed, the old conflict between different interests may even be intensified under the comprehensive national land-use planning to which Britain is committed. The long-term advantage to the country of conserving the best food-producing land may conflict sharply with short-term economic advantages.
The most serious aspect of land planning to-day is that much is being done by those concerned with the day-to-day work of town and country planning without an adequate understanding of the scientific background, while far too often the essential facts remain unknown. A good example is afforded by the present chaotic state of 'rural planning'. Stated simply, increased technical efficiency in agriculture permits the maintenance of a high level of production with a smaller labour force. Even when agricultural production is increased, heavy rural depopulation is still in evidence. With a changing age-composition of the population, the stage is soon reached when the village communities dependent primarily on the land are too small to justify the continuance of a school or the maintenance of those services regarded as essential to a modern standard of life. For example, whereas an average rural parish on good farmland such as may be generally found in the English Midlands had 80 children between five and nine to support the village school in 1871, the number to-day is not likely to exceed 34. Instead, therefore, of restricting housing in the village to workers connected with the land, an active policy of encouraging others to go and live therein appears the only hope of maintaining corporate rural life.

A gulf exists between the natural scientist and the professional town and country planner. Sometimes it is a failure of the latter to use and apply existing knowledge; often it is the failure of the man of science to carry out those particular studies which are most needed. The geologist has not yet provided a drift map; the geologist shows little interest in the lithological characters which determine whether a given deposit-for example, of gravel-is or is not of economic importance. There is no soil map of Britain, and the trend of pedological research often renders modern work of less practical value than the pioneer studies of Hall and Russell. A comprehensive survey of water resources, so long urged by Capt. W. H. Mclean before the British Association, is still an outstanding need. The value of given tracts of land for such purposes as intensive horticulture frequently depends on microclimatology ; yet there are few exact surveys to help the planner. Vegetation cover is accepted as an index of the sum total of environmental factors; yet ecologists have made little effort to produce a primary vegetation survey. Until some of these gaps are filled, the work of land-use planning must rest on a scientifically unsatisfactory basis.

In an old-settled country such as Britain, existing land use reflects the results of many centuries of trial and error-often the results of the interaction of geographical, historical and economic factors. The mapping and interpretation of the existing land-use pattern are fundamental contributions of the geographer to planning. Treated historically, the evolu. tion of the pattern shows trends in development or change, and land planning is simply the encouragement of such trends or positive action to change them.

The vexed question of land classification calls for the evaluation of many factors. This is well seen in the determination of the ten types made by Prof. Dudley Stamp as director of the Land Utilization Survey. Although giving a crude and highly generalized picture, the Land Classification Map of Britain (now published by the Ordnance Survey for the Ministry of Town and Country Planning on the scale of $1: 625,000$ ) does serve to indicate the distribution 